\title{
Aggressive (deep) angiomyxoma of the vulva: a case report
}

\author{
Lajya Devi Goyal ${ }^{1 \dagger}$, Priyanka Garg ${ }^{1 *+} \mathbb{B}$, Rama Badyal $^{2}$ and Shivali Bhalla ${ }^{3}$
}

\begin{abstract}
Background: Aggressive angiomyxoma of the vulva is a benign, slow-growing tumor originating from myxoid cells of connective tissue. The tumor is known for multiple local recurrences with a low tendency to metastasize. Only around 350 cases have been documented in the scientific literature so far.

Case presentation: We report a case of a 40-year-old North Indian, unmarried woman with a swelling on the left labium majora for 7 years, along with surface ulceration over the mass. Local examination showed a well-circumscribed, $8 \times 8 \mathrm{~cm}$ pedunculated mass arising from the left labium majora with an overlying ulcer measuring $6 \mathrm{~cm} \times 4 \mathrm{~cm}$. After taking informed written consent, wide local excision of the mass and surrounding margins was done under anesthesia. Histopathology was suggestive of aggressive angiomyxoma. Immunohistochemistry was done, which was positive for estrogen and progesterone receptors. Her postoperative recovery was uneventful. The patient was given three doses of gonadotropin-releasing hormone agonist (injection, leuprolide $3.75 \mathrm{mg}$ ) once a month. No recurrence has been reported so far on follow-up visits for 1 year.

Conclusion: Aggressive angiomyxoma is one of the differential diagnoses for vulvovaginal growth in a female. As the tumor is well known for local recurrences, correct diagnosis and appropriate management using a multidisciplinary approach are crucial to managing such patients.
\end{abstract}

Keywords: Angiomyxoma, Vulva, Gynecology, Local recurrence, GnRH agonist

\section{Introduction}

Aggressive angiomyxoma (AA) of the vulva is a benign, slow-growing, and locally invasive mesenchymal tumor originating from myxoid cells of connective tissue. It was first described in a case series of nine patients by Steeper and Rosai in 1983 [1]. The term was reclassified as deep angiomyxoma by the World Health Organization in 2003 [2]. It is a relatively rare tumor, with less than 350 cases reported to date [3]. AA occurs almost exclusively in women of reproductive age, with a peak incidence in the third to fifth decades of life [4]. It usually presents as

\footnotetext{
*Correspondence: priyanka.garg.u@gmail.com

†Lajya Devi Goyal and Priyanka Garg are co-first authors

1 Department of Obstetrics and Gynecology, All India Institute of Medical Sciences, Bathinda, Punjab 151001, India

Full list of author information is available at the end of the article
}

a painless mass in the vulvoperineal region. The word "aggressive" denotes its high tendency for local invasion and propensity to infiltrate the perivaginal and pararectal tissues. While mostly benign, the tumor is notorious for multiple local recurrences as high as $30-72 \%$ [5]. However, the tendency to metastasize is low. Due to the rarity of this tumor, the chances of misdiagnosis vary between $70 \%$ and $100 \%$, leading to improper and delayed treatment that adversely affects the patient's health. Wide local excision with negative margins and long-term follow-up remains the best course of management but often results in high morbidity. Adjuvant therapy in the form of gonadotropin-releasing hormone $(\mathrm{GnRH})$ agonists has shown promising results to prevent recurrences. We discuss a case of AA of the vulva that was successfully managed by surgical excision followed by injection original author(s) and the source, provide a link to the Creative Commons licence, and indicate if changes were made. The images or other third party material in this article are included in the article's Creative Commons licence, unless indicated otherwise in a credit line to the material. If material is not included in the article's Creative Commons licence and your intended use is not permitted by statutory regulation or exceeds the permitted use, you will need to obtain permission directly from the copyright holder. To view a copy of this licence, visit http://creativecommons.org/licenses/by/4.0/. The Creative Commons Public Domain Dedication waiver (http://creativeco mmons.org/publicdomain/zero/1.0/) applies to the data made available in this article, unless otherwise stated in a credit line to the data. 
of leuprolide to avert relapse of the tumor, and present a brief literature review.

\section{Case presentation}

A 40-year-old North Indian, unmarried, nulliparous woman came to gynecology Out Patient Department (OPD) with a swelling on the left labium majora for 7 years, slowly growing in size. There was ulceration over the mass associated with serosanguinous discharge. Past medical and family history was unremarkable. On general examination, the patient was moderately built and afebrile. There was no evidence of jaundice, anemia, cyanosis, lymphadenopathy, clubbing, weight loss, or any bowel and bladder function alterations. Her menstrual cycles were regular with normal flow. She was a known case of epilepsy and was on tablet levetiracetam $500 \mathrm{mg}$ once daily. She had a history of hemithyroidectomy 6 years back and was on thyroxine tablet $50 \mu \mathrm{g}$ once daily. Her abdomen was soft and nontender. On local examination, a well-circumscribed, $8 \times 8 \mathrm{~cm}$ pedunculated mass arose from left labium majora lateral to introitus at five o'clock position. On palpation, the mass was nontender, nonreducible, and soft in consistency. There was an overlying ulcer measuring $6 \mathrm{~cm} \times 4 \mathrm{~cm}$, and the floor was covered with unhealthy pale granulation tissue. There was mild serosanguinous discharge from the ulcer (Fig. 1). No inguinal lymphadenopathy was seen. On gynecological examination, the uterus was normal in size with a healthy cervix and vagina. Her baseline investigations were normal. Ultrasonography (USG) of the abdomen and pelvis was normal. Magnetic resonance imaging (MRI) could not be done due to financial constraints on the part of the patient. After taking informed written consent, wide

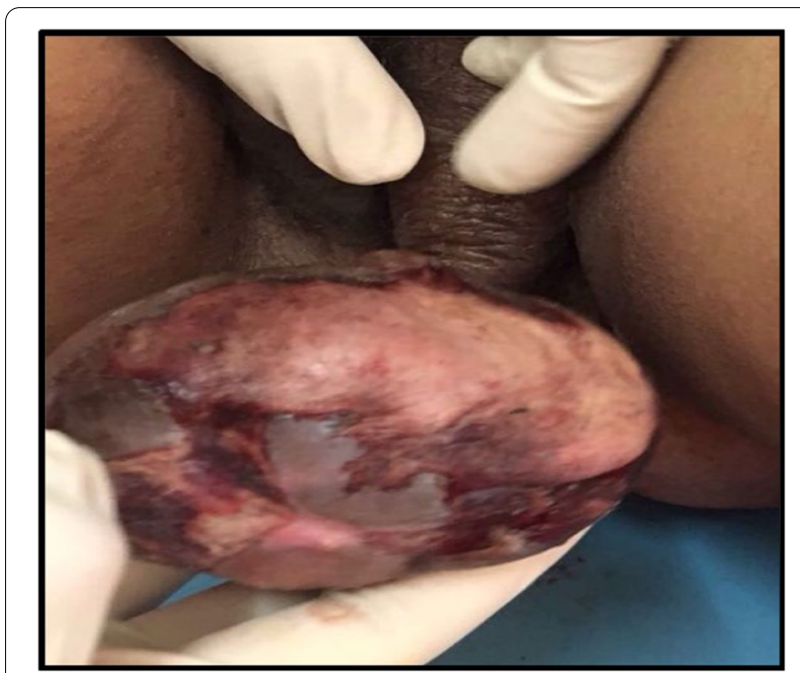

Fig. 1 A large, well-defined pedunculated mass arising from left labium majora with overlying skin ulceration local excision of the mass and surrounding margins was done under anesthesia. There was a moderate amount of bleeding during the surgery. The specimen was sent for histopathological examination. On histopathology, the tumor was composed of spindle and stellate-shaped cells in a myxoid matrix suggestive of aggressive angiomyxoma with tumor free margins (Fig. 2). Immunohistochemistry was done, which was positive for estrogen and progesterone receptors. Her postoperative recovery was uneventful. On the third day post-surgery, the patient was sent home in good general condition, with hemoglobin of $10 \mathrm{gm} \%$. Due to the high propensity of the tumor for local recurrences, the patient was given three doses of GnRH agonist (injection, leuprolide $3.75 \mathrm{mg}$ ) once a month. No recurrence has been reported so far on follow-up visits for 1 year.

\section{Discussion}

Angiomyxomas are recognized as superficial (cutaneous myxoma) or aggressive. Superficial angiomyxomas occur more commonly in middle-aged patients presenting as a single nodule or a polypoidal mass in the head and neck region, trunk, and lower extremities. They are easily confused with skin tags, cysts, or neurofibroma and are commonly associated with Carney's complex (a triad of cardiac myxomas, spotty pigmentation, and endocrine overactivity). AA is reported almost exclusively in women of reproductive age, with occasional cases seen in perimenopausal females and children. This may be attributed to the hormone-responsive nature of the tumor, as its growth is stimulated by estrogen and progesterone, backed by a case report of rapid enlargement

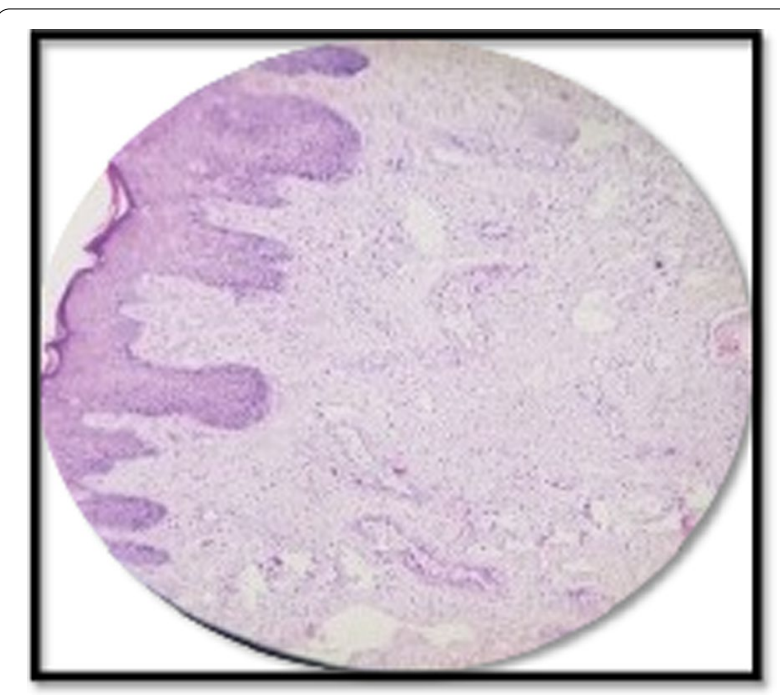

Fig. 2 Histological section [hematoxylin and eosin (H\&E), × 100] showing blood vessels of varying size against myxoid background 
during pregnancy [6]. The tumor is located mainly in the pelvis and perineal region. Other rare sites include lung, liver, larynx, and orbit [3]. Occasionally, they are seen in male patients in related sites like the scrotum and inguinal region. However, the ratio of occurrence in females to males is 6:1 [7].

The exact pathogenesis of AA is still unclear. However, since the tumor cells express desmin and smooth muscle actin, it is believed to originate either from specialized mesenchymal cells or from the multipotent perivascular progenitor cells [8]. High-mobility group protein isoform I-C (HMGI-C) gene located in the region 12q13-15 of chromosome 12 seems to play a role in the pathogenesis of this tumor. Abnormal expression of this gene, HMGI$C$, detected using the immunoperoxidase technique, may be a possible marker of microscopic residual disease [9].

The patient is usually asymptomatic and presents with a slow-growing pedunculated mass in the vulva, gluteal region, or suprapubic region. Nonspecific symptoms such as dull aching pain, the feeling of local pressure, dysuria, urinary retention, or dyspareunia may be present. The size may range from a few centimeters to $>60 \mathrm{~cm}$. The true extent of AA is frequently underrated on gross inspection as the clinically visible tumor exhibits only a fragment of the more widespread involvement of the deeper tissues of the pelvis and retroperitoneum.

Clinically, the tumor needs to be differentiated from angiomyofibroblastoma, Bartholin gland cyst, sarcoma botryoides, superficial angiomyxoma, vulvar hypertrophy with lymphedema, lipoma, and sarcoma. The histological differential diagnosis includes myxoma, myxoid liposarcoma, myxofibrosarcoma, and nerve sheath myxoma. Marked vascularity in aggressive angiomyxoma helps to differentiate it from most of the above neoplasms. The absence of lipoblasts differentiates it from liposarcoma. AA may be commonly misdiagnosed as angiomyofibroblastoma. However, the latter is well circumscribed, more cellular, and more vascular.

Preoperative imaging is extremely important to see the extent of the tumor and plan surgical excision accordingly. On USG, it is seen as a hypoechoic or cystic mass. The mass shows a distinct feature of swirled and layered tissue on computed tomography (CT) and magnetic resonance imaging (MRI). Wu et al. conducted a study to evaluate the role of $\mathrm{CT}$ and MRI imaging techniques. They elucidated that both $\mathrm{CT}$ and MRI precisely predict the extent of the tumor. However, MRI is more specific and is superior to $\mathrm{CT}$ when ascertaining the tumor's relation to the surrounding structures [9]. Thus, MRI is the investigation of choice for diagnosis and follow-up of recurrences.

Many treatment modalities have been tried with varying success. Radical surgical excision with negative margins is the conventional treatment of choice. However, it is not always possible to achieve negative resection margins as the tumor is locally infiltrative, leading to high operative morbidity. Therefore, less radical surgery is recommended nowadays. Adjuvant therapy in raloxifene, tamoxifen, or GnRH agonists like leuprolide acetate and goserelin have proven beneficial where the tumor is estrogen and progesterone receptor sensitive. In a case report by Fine et al., recurrent AA of the vulva was treated solely by 3 months of GnRH agonist without needing any other medical therapy or surgery [10]. However, its long-term use may not be acceptable to the patients because of unwanted side effects (menopausal symptoms and bone loss). The diagnosis of AA in our patient was elucidated after the histopathology report, so we administered three doses of leuprolide injection for any remnant disease and avoided recurrence. Radiotherapy and chemotherapy have a limited role owing to the low mitotic activity of the tumor. AA is known for multiple local recurrences to the extent of $36-72 \%$ and may occur as early as 2 months to as late as 20 years [11]. Begin et al. described nine AA cases with local recurrence, all due to incomplete excision [12]. Han-Guerts et al. suggested multimodality treatment for AA: excision of the tumor without mutilation, adjuvant therapy such as arterial embolization or hormonal therapy, and radiotherapy in symptomatic patients resistant to embolization/hormonal therapy.

The tumor was conventionally considered to be nonmetastasizing. However, metastasis has been reported as an exceedingly rare event in literature. Siassi et al. reported a death due to multiorgan metastasis invading the peritoneum, lungs, and lymph nodes [13]. In another case, it occurred in a 34-year-old woman who developed several local recurrences after primary resection of an $\mathrm{AA}$ and subsequently died from multiple lung metastases [11]. No evidence-based recommendations are available for post-surgery management of AA, but due to the high rate of local recurrences and possible metastasis, patients should be advised to undergo long-term follow-up until 15 years after the primary excision.

\section{Conclusion}

Aggressive angiomyxoma is a rare, locally aggressive neoplasm. It should be borne in mind as a differential diagnosis whenever a patient presents with growth in the vulvovaginal region, perineum, or pelvis. As the tumor is well known for local recurrences, timely diagnosis and management with surgical excision and adjuvant therapy are beneficial for such patients.

\section{Acknowledgements}

None. 


\section{Authors' contributions}

LDG was involved in patient management and taking consent from the patient. PG and SB were involved in the writing of the case report and followup of the patient. RB was involved in the histopathology of the tumor. All authors read and approved the final manuscript.

\section{Funding}

This research did not receive any specific grant from funding agencies in the public, commercial, or not-for-profit sectors.

\section{Availability of data and materials}

Not applicable.

\section{Declarations}

\section{Ethics approval and consent to participate}

This study did not conduct any experiments on animals or humans. The patient consented to the use of her personal data for the purpose of this case report.

\section{Consent for publication}

Written informed consent was obtained from the patient for publication of this case report along with the images. A copy of the written consent is available for review by the Editor-in-Chief of this journal.

\section{Competing interests}

The authors declare that they have no competing interests. The authors have no association with financial or nonfinancial organizations.

\section{Author details}

1 Department of Obstetrics and Gynecology, All India Institute of Medical Sciences, Bathinda, Punjab 151001, India. . ${ }^{2}$ Department of Pathology, Government Medical College, Amritsar, Punjab 143001, India. ${ }^{3}$ Department of Obstetrics and Gynecology, Guru Gobind Singh Medical College, Faridkot, Punjab 151203, India.

Received: 16 December 2021 Accepted: 18 January 2022

Published online: 18 February 2022

\section{References}

1. Steeper TA, Rosai J. Aggressive angiomyxoma of the female pelvis and perineum. Report of nine cases of a distinctive type of gynecologic soft-tissue neoplasm. Am J Surg Pathol. 1983;7:463-75. https://doi.org/10. 1097/00000478-198307000-00009.

2. Hanby AM, Walker C, Tavassoli FA, Devilee P. Pathology and genetics: tumours of the breast and female genital organs. WHO Classification of Tumours series—volume IV. Lyon: IARC Press: 2003. 250pp. ISBN 92832 2412 4. Breast Cancer Res. 2004;6:133-4. https://doi.org/10.1186/bcr788

3. Gaurav A, Gill P, Khoiwal K, Chowdhuri S, Kapoor D, Chaturvedi J. Aggressive angiomyxoma of the vulva - a rare entity: case report and review of literature. Int J Reprod Contracept Obstet Gynecol. 2020;9:2605. https:// doi.org/10.18203/2320-1770.ijrcog20202357.

4. Joseph S, Helm J, Villegas E, Figueroa-Bodine J, Anderson J. Aggressive angiomyxoma: a rare cause of a vulvar mass. J Med Oncol Ther. 2020:5:81-3. https://doi.org/10.35841/medical-oncology.5.1.23.

5. Rezai S. Aggressive angiomyxoma of the vulva in a teenager, a case report and review of literature. Obstet Gynecol Int J. 2016. https://doi.org/ 10.15406/ogij.2016.04.00128.

6. Orfanelli T, Kim C-S, Vitez SF, Van Gurp J, Misra N. A case report of aggressive angiomyxoma in pregnancy: do hormones play a role? Case Rep Obstet Gynecol. 2016;2016:1-4. https://doi.org/10.1155/2016/6810368.

7. Das B, Baruah D, Medhi K, Talukder B. An aggressive angiomyxoma of vulva - a rare entity-a case report. J Midlife Health. 2016;7:140-3. https://doi.org/10.4103/0976-7800.191020

8. Alameda F, Munné A, Baró T, Iglesias M, Condom E, Lloreta-Trull J, Serrano S. Vulvar angiomyxoma, aggressive angiomyxoma, and angiomyofibroblastoma: an immunohistochemical and ultrastructural study. Ultrastruct Pathol. 2006;30:193-205. https://doi.org/10.1080/01913120500520911.
9. Wu H, Liu W, Xu H, Wang D, Ouyang A. Aggressive angiomyxoma of the pelvis: a series of four cases and literature review. Eur J Gynaecol Oncol. 2015;36:610-4. https://doi.org/10.24327/ijrsr.2018.0902.1551.

10. Fine BA, Munoz AK, Litz CE, Gershenson DM. Primary medical management of recurrent aggressive angiomyxoma of the vulva with a gonadotropin-releasing hormone agonist. Gynecol Oncol. 2001;81:120-2. https://doi.org/10.1006/gyno.2000.6119.

11. Blandamura S, Cruz J, Faure Vergara L, Machado Puerto I, Ninfo V. Aggressive angiomyxoma: a second case of metastasis with patient's death. Hum Pathol. 2003;34:1072-4. https://doi.org/10.1053/S0046-8177(03) 00419-2.

12. Bégin LR, Clement PB, Kirk ME, Jothy S, Elliott McCaughey WT, Ferenczy A. Aggressive angiomyxoma of pelvic soft parts: a clinicopathologic study of nine cases. Hum Pathol. 1985;16:621-8. https://doi.org/10.1016/S00468177(85)80112-X.

13. Siassi RM, Papadopoulos T, Matzel KE. Metastasizing Aggressive Angiomyxoma. N Engl J Med. 1999;341(23):1772-72.

\section{Publisher's Note}

Springer Nature remains neutral with regard to jurisdictional claims in published maps and institutional affiliations.
Ready to submit your research? Choose BMC and benefit from:

- fast, convenient online submission

- thorough peer review by experienced researchers in your field

- rapid publication on acceptance

- support for research data, including large and complex data types

- gold Open Access which fosters wider collaboration and increased citations

- maximum visibility for your research: over 100M website views per year

At BMC, research is always in progress.

Learn more biomedcentral.com/submissions 